\title{
4
}

\section{An Association Between Diversity and Exoticism}

At the end of the last concert of the three-day FusIran festival, which the Golestan association co-organized in one of Hamburg's most important nightclubs, Shahrokh Moshkin Ghalam dances to the music of the Italybased classical Iranian music group Barbâd. He wears a dark grey dervishlike dress; his waist-long hair is swirling. Spontaneously, the dancer invites female members of the association to join him onstage. Shahla is the first to join. I am surprised, because she told me that she did not know how to dance to Iranian music at a party a month earlier. Then, Said Shanbehzadeh, who performed the previous concert of Southern-Iranian Bandari-style music, jumps on the stage. The Paris-based musician has exchanged the simple cloth reminding African tribal clothes for a beige costume. As I walk around in the crowd of about 200 persons (according to Sadegh the public was constituted to $70 \%$ of Iranians and $30 \%$ of Germans), Yalda meets me and says: "Go, join the others on the stage!" I am embarrassed, but I go anyways as virtually all Golestanis including some of their family members are dancing together with the artists, thus symbolically concluding the festival. (Field notes, October 2013)

The moment I stepped on the stage, it felt as if I was part of a group united not only by the celebration of the successful completion of three 
intense days of volunteering. Dancing with these internationally renowned Iranian artists-Moshkin Ghalam and Shanbehzadeh reinterpret Iranian traditional and folk culture ${ }^{1}$ for Western and Iranian migrant publics — was also a way for each member to individually show his identification with neo-traditionalist Iranian cultural elements in front of the public. In that instant, we, the dancing Golestanis, were united through our situational collective identification.

Since the mass immigration of the 1980s, Iranians' continuously growing diversity of social backgrounds, levels of education, ethnic identities, religious and political beliefs give rise to a proliferation of Iran-related associations in Hamburg. There are cultural and ethnic associations, professional unions (like the Union of Iranian Entrepreneurs, see Chap. 3), religious groups (the association of the supporters of an Iranian-Shia mosque), and political associations. During my fieldwork, I repeatedly heard people report about conflicts within these associations. For example, Ehsan, a 50-year-old academic, told me that, several years ago, the literature circle Hamneshast split over the disagreement of two board members. Babak, an artist in his early forties, told me that he did not join Hamneshast although the topics it treated interested him, because "there are always people who spoil it [for me]; conservative people who play to the gallery" (field notes, April 2013). Given the great diversity of individual trajectories and the multiplicity of identifications among Iranians in Hamburg, what boundaries do people mobilize to create and maintain collective identifications within such a migrant association?

According to Pierre Bourdieu (1979, 182, 355), in associations and clubs organized around a common activity or feature, social distinction can be studied through processes of inclusion and exclusion. Indeed, associations are spaces where members can create capital (idem 1979, 533). More specifically, one can build networks and acquire new skills and cultural knowledge, for example, organizational know-how and language skills, and thereby gain a greater participation in the society of residence, and, if applicable, in transnational social fields (Cattacin and

\footnotetext{
${ }^{1}$ While Moshkin Ghalam mixes traditional Iranian, Sufi, Flamenco dance elements with martial arts styles, Shanbehzadeh performs folklore music and dances from the southern Iranian province of Bushehr.
} 
Domenig 2014; Prashizky and Remennick 2015). While migrant associations are mostly based on a shared identification with a national or ethnic category, their collective identity references often contain elements both of the society of origin and of the place of residence (Cattacin and Domenig 2014).

So far, my research illustrated that ethnic and national identifications, informed by personal experiences and professional trajectories, are tools within flexible strategies of capital creation. In the context of carpet merchants of Iranian origin, I showed that collective identifications-in the form of professional narratives - may emerge, as a way to engage in politics of value that serve to fine-tune the values certain resources mediate and thus navigate the simultaneous capital creation in several social fields. Consequently, agents' politics of value constitute the motivation that drives their performance of capital creation. Extant research shows that, in providing collective identity references, migrant associations propose cultural representations that may help to overcome certain barriers to capital creation (Ghorashi 2004; Amelina and Faist 2008, 113f.). My aim in this chapter is to examine how processes of evaluation within an association relate to systems of value that prevail in the social fields relevant for the association's activities.

Understanding boundary-making as the denial of a resource's value, and the deconstruction of a boundary as the valorization of a resource as a capital, I examine the inclusion and exclusion of people in the Hamburg branch of the German-Iranian association Golestan, from its foundation in 2011 until 2015. Through a diachronic analysis, I trace how members, post-1979 highly educated first- and second-generation migrants, individually and collectively put forward different identifications in relations with German media, among established Golestanis, and in contact with prospective members. Thus, interrogating the formation of group identifications from within, I aim to shed light on the way unequal individual resources drive the collective potential for action in politics of value in the German public sphere, in the local Iranian social field, and the transnational social field of Iranians identifying as honari.

I first learnt about Golestan through Roshan, a woman in her early thirties, who had been my flatmate a few years before the association was founded. She posted an advertisement for their annual Nowruz festivity 
on Facebook. Intrigued by its venue, unusual for Iranian events (a Steiner school), I joined the celebrations that took place in March 2013. In this frame, I met Babak, who invited me to join Golestan's first Stammtisch ${ }^{2}$ in May 2013, after we met several times over a coffee or a beer. Situations in which I felt included in group dynamics became more and more frequent in the course of research. This was not only due to my regular attendance of the monthly Stammtisch, but also to my participation in private meetings, barbecues, and nights out with some of the Golestanis. My involvement became more important through my volunteering in the organization of the three-day-long FusIran festival and the 2014 Nowruz festivities. Yet, to learn about the beginnings, I had to draw on interviews and media documentation.

\section{New Beginnings in Old Familiarity}

In the frame of the 2009 protests in Iran that accused the government of election fraud, Donya, a physician, and Sadegh, a successful poet and writer, respectively 34 and 39 years old, engaged in different forms of transnational activism in Hamburg. Their move reflects a growth of interest in Iran-related associations among young people of Iranian origin all over the world within this social upheaval (Alexanian 2011; Kelly 2011, 450f.). However, both told me that they soon reached the social and political limits to this kind of activism. As they shared the idea of engaging in cultural, rather than outrightly political work, their common friend Babak introduced them to each other. Sadegh suggested founding a local branch of Golestan, an association his friend Davud, an editor, was creating in Munich. In doing so, he explained me, he wanted to reduce administrative work and prevent struggle over the association's leading principles:

The [Golestan association] intends to be a place where German-Iranians can pursue those longings which they are not able to fulfill elsewhere.

\footnotetext{
${ }^{2}$ Stammtisch is a German concept, referring to the regular meetings of a stable group of people in the frame of associational or friendship circles - a concept that has parallels to the Iranian dowreh. Distinct from Golestan's official members' meetings that took place behind closed doors, the idea of these gatherings is to offer an open space for people interested by the association in which they can get acquainted with its members in an informal setting.
} 
At [Golestan] we would like to create a space where we can further develop our individual concept of the term "home" [...]. It's [Golestan's] goal to provide a place for [...] diversity. A place where it can be experienced not only by German-Iranians but also by "native" Germans as well as people with a German-French, German-Turkish, German-Ghanaian (etc.) background [...]. One of [Golestan's] main goals is to provide a forum for a dialogue between cultures. It is a place of mutual respect and common experiences, where different views and concepts of life are tolerated. (Website of association Golestan, assessed 07/11/20153)

In other words, the association's declared aims were to provide identifications for people of Iranian origin, and a space where people of any ethnic background can live and experience the diversity of what is defined as "Iranian culture".

Seven people of Iranian origin, aged between 25 and 41, and linked by kinship or long-term friendship, created Golestan's Hamburg branch in 2011: Donya, her sister and brother, Sadegh, Roshan, her brother Afshin, Yalda, a female journalist called Shahla, and Babak. Some came to Hamburg as young adults; others were born in Germany or raised in different countries in the West. Donya explained "these were all people I knew and trusted" (interview, November 2015). She said that all were either themselves left-wing Iranian regime-critical activists, or their family members, or both. They were university-educated professionals or students and shared an interest in art. Many actually had personal ties in the Iranian artist milieu: Donya had set out to be a professional piano player before her migration, Sadegh and Babak had participated in art productions in Iran, and Yalda occasionally worked as a piano teacher in Tehran. Others, like Roshan and Donya's brother, were amateur dancers. Plus, Donya's uncle had worked with Yalda's father in Iran. Thus, as frequently observed in research on migration (Moya 2005; Kelly and Lusis 2006, 841 ), the association was originally based on pre-migratory social networks.

Their shared ties to Iranian artist subculture testify of an urban salaried middle-class background in Iran (Tehran and Shiraz), and identitary links to the intelligentsia (rowshanfekrân). Ervand Abrahamian (2008,

\footnotetext{
${ }^{3}$ In order to maintain the anonymity of the association, I do not indicate the web address.
} 
34ff.) dates the origins of this identitary group, which draws on a dialectical opposition to the propertied middle class, the merchants, back to the presence of foreign military and economic powerholders in Iran in the nineteenth century. A picture from 2012 that figures on the association's website shows some of the foundation members including Yara. They pose in front of a building covered with graffiti, probably located in the Schanzenviertel, a district marked by undergoing gentrification, where alternative subcultures meet yuppie lifestyles (Naegler 2012), thus underlining their linkage to local alternative culture. Moreover, Yara's green jacket and Yalda's green scarf support the protestation movement against the elections in $2009 .{ }^{4}$

Associations serve as sites of distinction; this is also the case for migrants. Anna Prashizky and Larissa Remennick (2015), for instance, show how among young people of Russian origin in Tel Aviv create an association to collectively reinterpret a culturally hybrid Russian intelligentsia lifestyle. In doing so, they draw boundaries to Russians with different social and migratory trajectories, and they aspire for upward social mobility through the recognition of their Russia-related cultural capital by local Israelis. Such a recreation of socio-professional identities after migration is reminiscent of Iranian carpet merchants' politics of value. Trust created through long-term relations plays a crucial role here, too. However, we shall see why, at the difference of carpet merchants, Golestanis seek to stress their Germany-specific capital or claim cosmopolitan, rather than primarily Iran-related tradition-orientated identifications. Thereby, the mobilization of the system of value that prevails in the transnational social fields of Iranian artists, in other words, the local reinterpretation of the "honari imaginary", plays a crucial role in the association's original politics of value.

\section{A Honari Imaginary}

When I attended Golestan's Nowruz festivities in 2014, I had just come back from a research stay in Iran. The event featured a stand on which I recognized some of the same handcrafted goods-jewelry, scarves, key

\footnotetext{
${ }^{4}$ Green was the color of the unsuccessful reformative candidate Mir-Hossein Mousavi.
} 
fobs, and so on-I had seen on one of the biggest markets of small artisans in Tehran, pâssâj parvâneh. I was told that one of the newer members had brought them back on her last visit. As this instance indicates, the members' personal connection with the transnational Iranian art milieu influenced the choice of Iran-specific resources Golestan put forward. Significantly, according to Donya, one of Golestan's initial aims was to offer a platform to contemporary young artists, who lack the permission of the ministry of culture and Islamic guidance to work legally in Iran. The FusIran festival was supposed to be such an occasion.

To understand the role of this identification in dynamics within the association, we have to take into account which values these art-related resources mediate in Iranian contexts. Obviously, the complexity of the social dynamics in Iran's art milieu would require a research on its own (see Emami 1986; Grigor 2012). For the purpose of this chapter, I confine myself to drawing the great lines of the honari imaginary which developed around this artist milieu. I chose the term "imaginary" to account for the constructiveness and fluidity of the ideas and practices that shape identifications with artistic subcultures.

I first got in touch with people who call themselves - and are identified as-honaris ${ }^{5}$ thanks to some of my family members living in Iran, who are art professionals or amateurs. Ideas and practices that refer to honari identifications are highly diverse, but, without falling into simplifications, I will identify a few recurrent markers. First, the common ground on which such identities rely is an interest in the fine arts, at least in the general sense. This interest implies a rather high level of education, often linked to a middle-class background.

Second, many people who identify as honaris valorize Iranian traditional (sonnati) cultural elements (in particular literature, folklore music, folkloric designs) as well as European high culture (e.g. Italian architecture, French literature). This neo-traditionalism may go together with a distancing from the global Western-oriented consumer culture (Sadjed 2012, 156). Babak, for example, told me that when he is in Iran, he likes to spend his evenings at the café of the "Mohsen art gallery" located in a

\footnotetext{
${ }^{5}$ The term is best translated as "arty people", which, in contrast to artists, honarmandân, includes also amateurs.
} 


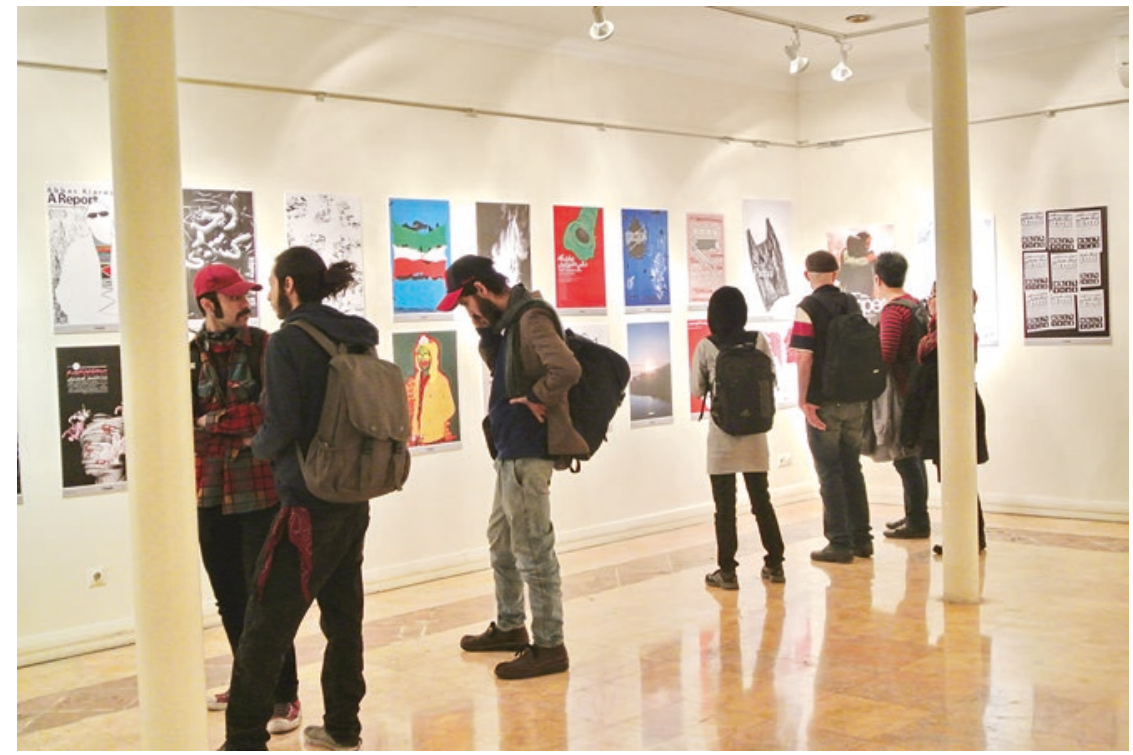

Image 4.1 Young men whose clothing and hairstyle mark their honari identification at Khâneh honarmandân, center of contemporary art, Tehran. (February 2014, author's photo)

high-end quarter in Northern Tehran and specialized in avant-garde art, because "you can meet people there who are less consumption-oriented as the rest of the society" (field notes, March 2014).

In Iran and abroad, people enact the honari imaginary through consumption practices, ${ }^{7}$ which may contain elements that can be found in Western alternative subcultures. For example, wearing colorful and large clothes inspired by Iranian folklore may evoke Western hippie styles. Large glasses, as well as beards and mustaches for the men do not only reflect Iranian neo-traditionalism but also the influence of the Westernoriginated hipster trend (Image 4.1).

Gendered behavior that contests patriarchal and Islamic norms is also a way for honaris to seek distinction from urban mainstream lifestyles. For

\footnotetext{
${ }^{6}$ Babak "Da trifft man Leute die nicht so konsumorientiert sind wie der Rest der Gesellschaft".

${ }^{7}$ Public locations in which I could observe people displaying such a lifestyle are (clandestine) cafés, tea houses, parks, art galleries, theaters, or handicraft markets in Tehran and Mashad.
} 
example, while physical closeness between non-related persons is considered sinful (harâm) according to Islam, in winter 2013, I saw a male friend and colleague of a female graphic designer-ten years her junior-spontaneously kiss her on the forehead on a street near Tehran's Vanak Square.

In sum, identifying as honari tends to mean putting forward certain social and cultural resources that would mediate education, knowledge of Iranian (pre-Islamic) traditions, literature, acquaintance with Western high culture, and its values of democracy, equality, human rights, and sometimes even socialism (Abrahamian 2008, 35). Simultaneously, the same people downplay resources that would convey Islamic piety, political loyalty to the Iranian government, patriarchy, but also global cultural hierarchies, or capitalism as these contradict the aforementioned key values within the system of value that shapes honari contexts (see also Sadjed 2012, 156f.). It thus tends to express opposition or at least a critical stance toward the Iranian regime.

In recent years, however, the honari lifestyle became part of a more mainstream urban neo-traditionalist trend in Iran. Significantly, 15 years ago, shops selling artistic and craftwork could be found only in rare touristic places or traditional workshops. However, I noticed a burgeoning of stores selling (rather expensive) pottery, jewelry, locally designed folkloreinspired clothes and leatherwork in big cities since the mid-2000s (Image 4.2). ${ }^{8}$ This development is the result of several—quite contradictorysocial and political influences. First, the government encourages a revival of "authentic Iranian culture" as a nationalist resistance against Westernization, in particular in artistic productions (Keshmirshekan 2010, 492). We saw some of this politics in the governments' hailing of carpet knotters in Chap. 3. Second, the identification and revival of preIslamic Iranian cultural elements among people of Iranian origin living in Western countries, which Kathryn Spellman (2004, 43) calls the "syncretic re-archaization", stimulates this interest. ${ }^{9}$ Thus, the neo-traditional tendencies in Iran led to the increasing commercialization of artists' and

\footnotetext{
${ }^{8}$ Shahram Khosravi $(2008,69)$ also testifies about the appearance of traditional tea houses (châi khâne-ye sonnati) in Tehran's Northern high-end districts.

${ }^{9}$ There is, for example, a new interest in Zoroastrian festivities such as Tirgân and Mehregân among urban middle classes. Significantly, my father told me in 2013 that he had participated in an outdoor Tirgân festivity with a hundred other people in the Northern province of Mazanderan-a festivity which he had known neither in his youth in Iran, nor during the time he lived in Germany.
} 


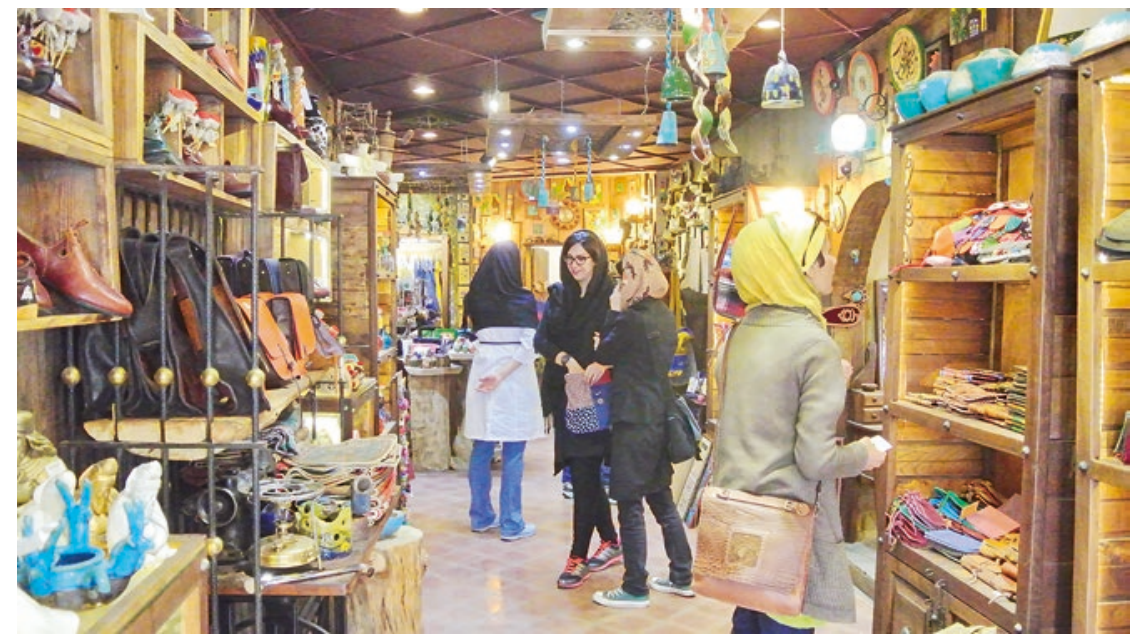

Image 4.2 A store in central Tehran selling honari artifacts. (February 2014, author's photo)

artisans' work, bringing images linked to their lifestyle to the center of society.

Having thus outlined the Iranian identifications the founder members sought to promote, I move on to examine the interaction between individual members' identifications within a German public media appearance, in order to set the context for the subsequent analysis of internal boundary-making.

\section{A Public Negotiation of the Limits to Identifications}

One year after its foundation, in mid-2012, the Golestanis Afshin and Yara participated in a TV program, which has the aim to present nonprofit organizations' projects to prospective donors and sponsors. Besides members of Golestan, there was also the vice-president an association of people from Burkina Faso.

Afshin, a founding member, is an introverted 28-year-old student of law. As opponents to the Islamic Republic, his parents sought asylum in 
Hamburg, where he was born and raised. Like Roshan, Afshin was my flatmate a few years before I started this research. Three years older Yara, who I met during my fieldwork, joined Golestan a few months before its first public event. The educator was born in Iran, came to Germany with her family at the age of five, and grew up in Lüneburg, a city south of Hamburg. The family then moved to Hamburg in the mid-2000s. Contrary to Afshin's parents who strictly oppose Islam, Yara told me that her mother, today member of a local female Iranian folklore band, regularly took her to the Iranian mosque in Hamburg when she was a child. Afshin never went to Iran, but Yara traveled there once when she was 21. However, she told me that, in engaging into anti-government activism in Hamburg in the frame of the 2009 upheaval, she resigned to not being able to go there anymore. Thus, both Golestanis can be considered second-generation migrants with German citizenship. However, their stances toward Iran and their engagement in local Iranian social fields could hardly be more different: Afshin has been keeping distance from Iranian contexts, and his friends are of various ethnic and national origins. His participation in Golestan was a first step toward an engagement with local Iranians. As for Yara, she has been strongly engaged in Iranian social fields since 2009.

In her introduction to the talk show, the journalist-a German without migration experience-quickly introduces the associations. Then, however, she questions Afshin and Yara about their Iranian identifications, asking:

Where are you from?

and to Afshin,

You were born here - how much Iranian is there actually still in you?

and to Yara,

You came to Germany at the age of five. How do you feel? Somewhere in between? 
The journalist sets out to focus on Afshin's and Yara's Iran-specific resources. Her first questions show her interest in their mediation of exoticism. As we saw in the previous chapter, this value was created through centuries of exchanges between Europe and the Middle East and closely connects to the quest for the culturally authentic (Halter 2007).

How did the Golestanis engage with this categorization? Afshin's strategy is to withdraw any ethnic or national significance from resources which the journalist interprets as Iranian:

I absolutely don't like to speak with [i.e. in terms of] "somehow being German or Iranian or so". Um, of course there is some kind of rootedness, my parents are from there, but ultimately, I was socialized here, I grew up here, and it is here that my life takes place [...]. So, it's not that we [i.e. Golestanis] only address Iranians - if you want to speak like this, in these categories - but actually all people who somehow identify with and who somehow look for a platform where this mix, precisely this "not clearly fitting somewhere" is echoed.

Afshin's refusing to adhere to any strictly defined ethnic or national identity is infused by his postcolonial understanding of nationhood and identity, not least through his sister's anti-racist activism in the group kanak attak ("wog attack"). Afshin tries to redefine the value mediated by non-European resources from exoticism toward diversity, and ultimately, familiarity. In doing so, he participates in a form of activism that grew popular in German-speaking contexts in the 2000s, as Fatima El-Tayeb (2004) and Sabine Strasser $(2006,2008)$ document. To be precise, I am here referring to diversity as a value ${ }^{10}$ (that is increasingly used in politics and public discourse (Schiller 2016; Bührmann and Schönwälder 2017)), which implies an acknowledgment of variety from the vantage point of adherence to a particular local cultural context. Significantly, in trying to turn the conversation away from his individual case, toward the identity of Golestan, Afshin defines the association as "not exclusively Iranian". Contrary to Afshin, Yara presents herself as German, but simultaneously indicates the limits to this identification:

\footnotetext{
${ }^{10}$ When I refer to diversity among Iranians, I intend the diversity of positioning in internal relations in the sense of plurality.
} 
I always say "I'm German" and then... I mean it is funny because people look at me and say "Well, you don't really look German." My question then is always "What does 'German' look like?" I mean, I'm German! If I feel this way, that's also what I am [she laughs].

Yara has black hair, dark, brown eyes, her skin has an olive tone, and she speaks German without any accent. The evaluation of her racial features thus became the reason why her interlocutor did not recognize the value of familiarity in her Germany-specific resources (see also Ong 1999, 91). In this TV show, she recounts these dynamics as a funny anecdote, but during my fieldwork I witnessed her being deeply affected by similar experiences. Boundary-making based on racial and religious difference is very common in German society and it constitutes important obstacles to migrants' capital creation (Weiss 2001; Goldberg 2006; Mandel 2008; Shooman 2014; Çelik 2017).

The first interactions between the journalist and the Golestanis raise a dichotomy prevalent in conceptions about immigration in Germany, which Martin Sökefeld (2004) termed the "paradigm of cultural difference": identifying as German and having other ethnic or national identities tends to be seen, if not as impossible at least as incompatible. I previously argued that, within German approaches to immigration, assimilation ultimately promotes the value of familiarity (see Chap. 3). Let me elaborate on this argument. In comparing the nature of symbolic boundaries against immigrants in Europe, Christopher Bail $(2008,49)$ shows that in Germany, education, occupational achievements, and, importantly, Germany-specific cultural resources, such as language skills and cultural knowledge, are seen as criteria for successful integration. Thus, familiarity is a key value and its mediation is essential to capital creation in dominantly German social fields. ${ }^{11}$

Moreover, the exotic and the familiar are perceived as mutually exclusive. Assimilation tends to be seen as the migrants' responsibility rather than as a collective process (Gruner 2010, 285; El-Tayeb 2016). This development is reflected in recent modifications in

\footnotetext{
${ }^{11}$ A similar importance of location-specific resources and the tendency to deny recognition of resources created abroad was observed in Sweden by Maja Cederberg (2015) — in spite of the government's political valorization of diversity.
} 
German citizenship legislation. Until the year 2000, citizenship was acquired primarily through filiation, based on the jus sanguinis. ${ }^{12}$ After that date, a legislative reform introduced the jus solis-the acquirement of citizenship through the birthplace (Bundesministerium der Justiz und für Verbraucherschutz 2015). However, dual citizenship is restricted to only those few nationals, whose country of origin makes expatriation difficult if not impossible, like Iran (Gaserow 1995). In short, the legislation suggests that you can be a German or a foreigner, but only with great difficultly can you be both. Correspondingly, resources created in transnational social fields tend to be perceived as unfamiliar and thus as a proof of a failure to assimilate (Ehrkamp 2006; Çelik 2015). Hence, in the system of values that shapes the German public sphere, that is, the social field in which the TV channel's production participates, Golestanis cannot both be Germans and be Iranians, nor can they be neither.

Because of this dichotomy, both Afshin and Yara resist the identification as Iranian and thereby contest their Iran-specific resources mediating exoticism. They aim to create, within Golestan, something Nicholls and Uitermark (2016) termed "counterpublic". We can think of it here as a social field whose system of value builds on an opposition to contexts in which their Iran-specific resources and racialized difference is perceived as a lack of familiarity. Yet, we will see in the following that, beyond the interest in not conveying exoticism, Afshin's and Yara's politics of value, and consequently, their strategies of capital creation, diverge.

Initially, the journalist shows interest in the Golestanis' contestations, for example, in suggesting the creation of a new social category that may reflect their cultural in-betweenness. However, instead of talking about the work of Golestan, or about aspects of Afshin's and Yara's life that are not related to Iran, she soon returns to inquiring about their "Iranianness", but now addresses Iran-related political issues:

\footnotetext{
${ }^{12}$ Accordingly, people who, like Afshin, were born to foreign nationals on German territory had to go through a formal citizenship application procedure to gain a German passport. This contributed to the categorization of children of migrants born and/or raised in Germany as foreigners, rather than Germans (Çelik 2015).
} 
Iran unfortunately also makes the headlines. Mahmoud Ahmadinejad, the dictatorship... that is unfortunately what the normal citizen knows about Iran since 2005. Do people ask you frequently about this?

\section{And}

How do you feel when you are, so to say, in Germany and talk is about Iran? With what feelings do you follow such news?

Essentially, the journalist refuses both Afshin's and Yara's identifications and continues to consider them as Iranian. Moreover, she uncritically raises popular preconceptions about Iran (and Burkina Faso ${ }^{13}$ ), judging the right and wrong of ideas and practices that do not correspond to the values of democracy and human rights. To defuse the journalist's judgment, Afshin and Yara state that, in their own social environment, people would have more nuanced images of Iran. In other words, the systems of value that shape the social fields in which they are engaged in their everyday lives are distinct from those prevailing in the German public sphere.

The journalists' evaluation of Iran-specific resources brings us to the second reason for the Golestanis' rejection of their categorization as Iranians: while these resources may convey exoticism, they also may be perceived as failing to convey the values of democracy, human rights, and equality-ultimately, familiarity with German contexts. Moreover, in the German public sphere, the value of exoticism is subordinated to the central importance of familiarity. In the case of carpet merchants, I showed that failing to mediate these values tends to create a barrier to Iranians' capital creation, for instance in the context of the Iran House project. Building on Iran-specific resources to convey exoticism is thus a risky strategy. Thus, Afshin's and Yara's politics of value aim at circumventing this potential barrier to capital creation by trying to convey familiarity, either in emphasizing the non-ethnic character of their Iran-specific resources and conveying diversity, or by putting forward Germany-specific resources. As the interview continues, Afshin sticks to his rejection of

\footnotetext{
${ }^{13}$ For example, in talking about Burkina Faso, the journalist inquires about female genital mutilation.
} 
national or ethnic categories against the journalist's quite insisting questions in an increasingly sarcastic way:

It's not as if, because my parents are from Iran, I am the one in charge of informing people about the actual state of the nuclear conflict. This is absurd, really.

He rebukes the journalist:

Journalist "Is there something where you would say [two seconds of hesitation] 'Iranians are really good in this, or one has to see that'?"

Yara [laughs].

Afshin "Now you hit on exactly the same line of argumentation that I just mentioned. I mean, there is no such thing as a 'typical Iranian this or that'."

At this point, Yara changes her politics of value. She gives up on trying to mediate familiarity. In a cheerful tone, she presents her Iran-specific resources in a way for them to convey the value of exoticism by putting forward Iran's ethnic and linguistic diversity.

We want to show a different image of Iran. I mean, um, our Iranian nation is a potpourri [kunterbunt], we have a multiethnic state, we have many, many languages in Iran that I even may not understand... we are really a potpourri, and that's exactly what we want to convey.

The effort to redefine the meaning of resources is a collective response to stigmatization frequent among ethnic minorities (Fleming et al. 2012). Significantly, like Yara, the invitee from the Burkina Faso association also engages in "identity entrepreneurship" (Brubaker and Cooper 2000). Research on Iranian associations and public events in the USA and the Netherlands equally suggests that they are sites for the production of Iranian identifications alternative to negative images prevailing in the media (Ghorashi 2004; Ghorashi and Boersma 2009; Malek 2011). As Yara draws an ethnic, that is, tentatively non-political, picture of Iran, and explains that her family identifies as ethnic Azeri, she accepts her categorization as Iranian (note also the usage of the first-person plural in 
the previous and the following citations). She distances herself from the Iranian government in order to sustain the values of democracy, human rights, and equality. In sum, Yara ends up complying, instead of engaging with the system of value that shapes this public media broadcast. As Nicholls and Uitermark $(2016,9)$ indicate, "rather than carving open a space in the public sphere, the expression of an identity that stood in opposition to dominant norms resulted in closure" and most often migrants resolve to conform to the expectation of exoticism and the struggle toward the impossible fulfillment of assimilation and familiarity.

For his part, Afshin successfully continues to reject any strictly defined national or ethnic identification, until, at the end of the interview, the journalist touches on his parents' political exile. As he shows personal affectedness for the first time, she comments in a pitiful tone that those who are forced to flee "leave something behind"-a statement that reflects stigmatization of people categorized as political refugees. This time, Afshin does not contest the journalist. However, Donya remembers that he was very angry after the broadcast, asking what the point of his participation was. Ultimately, in drawing on the value of diversity, he uses a concept that is itself a substantial part of discriminatory approaches to immigration, as Suzanne Hall (2017) notes. The Golestanis' persistent ascription to an assumed cultural alterity reveals that, within the system of value that shapes the German public sphere, resources that convey exoticism are less efficient, lasting, and versatile in creating capital than those who convey familiarity. The ultimate failure of both Afshin and Yara to mediate familiarity highlights their limited potential for action within social field that are shaped by this system of value.

Finally, their individual ways of engaging this system of value in the context of this TV show also indicates diverging ideas about Golestan association. While Afshin sees in the association a space for celebrating diversity as familiarity through activities that only loosely relate to the Iranian cultural context, Yara views it as a platform for exclusively Iranian contemporary art and cultural performances that cater to the mediation of exoticism.

It is on the background of navigating systems of value that promote familiarity while making it quite impossible for migrants to convey that we need to understand the negotiation of collective identifications within the association. 


\section{The Conflict}

In the process of collective identity formation, a conflict led to a split in the group between late 2012 and early 2013 and set the common ground on which collective identifications from then on would be negotiated. Roshan, who has a critical distance for being a PhD student abroad since 2012, resumed the conflict as follows:

As I think about it now, it was really a lot about identity negotiations, both about personal Egos, and about collective Egos in relation to Iran. (Private message on Facebook, October 2015)

Roshan's brother Afshin was the first to quit Golestan in late 2012. As became clear in the previous section, in the association, Afshin wanted to create a counterpublic which could reshape the dominant systems of value in German society by promoting diversity as familiarity. Significantly, Babak commented about him:

When he was at Golestan, he only complained about everything - the typical problem of leftist people. He wanted to make it more intercultural. What do I have to do with North Koreans? An association has a goal. I do that for a specific reason. To build up a network. [For me it is] not like [for] people like him, who are familiar with the place - this is their country, their language, their parents live here. But we need such networks. (Field notes, April 2013)

Thus, Babak attributes the difference between his own and Afshin's conception of Golestan primarily to the latter's political orientations which he qualifies as being too left-wing, or him being born in Germany-in other words, disposing of more Germany-compared to Iran-specific resources. As became clear in the preceding sections, the national or ethnic origin of resources plays a major role in their evaluation in the German society. Therefore, they are also highly relevant in social differentiation between Golestanis (see also Ehrkamp 2006).

In the case of the two men, their different disposition and volume of resources and their engagement in distinct social fields gave rise to poli- 
tics of value that engendered conflicting strategies of capital creation. While both men met with barriers to capital creation based on their categorization as Iranians in many German contexts, German-born Afshin disposed of less Iran- and more Germany-specific resources than Babak. His chances to circumvent these barriers by mediating familiarity, through his local rootedness for instance, were thus relatively better than those of his older peers. For his part, Babak, who grew up in Iran, had accumulated frustrations for failing to overcome the barriers his Iran-specific resources posed to his capital creation. In co-founding Golestan, he told me that he wanted to create a network of Iranian professionals in the art sector-a social field whose system of value would acknowledge both his Germany-specific and his Iran-specific resources as capital, and which would help to balance barriers in German contexts and simultaneously sustain the value of exoticism.

Initially, Roshan, Donya, and her siblings supported Afshin's nonexclusive approach to the association's Iranian identifications, while Babak, Sadegh, and Yara, who entered the association in early 2012, argued for a greater focus on Iran. This relative balance changed when, after its first public event in March 2012, more and more people joined Golestan (through a mandatory written application): there was Golzar, a 41-year-old makeup artist, who came to Hamburg in the early 1990s, and brother Mahyar, a recently graduated lawyer on job search. Ayda, a woman in her early thirties plays the santur, ${ }^{14}$ and Farzan, an engineer in his mid-thirties, were also among the new members. All of them nourished Azeri identifications, but ethnic identities never played a role in the association. Finally, there were 23-year-old Said, a student of informatics, and Younes-respectively German-born and born to a binational couple in Iran. Except for Younes, the newer members, although mostly university-educated, were of more modest origin, less politicized, less successful in generating capital in German social fields than most of the founders. On the whole, the newcomers were interested in fostering specifically Iranian collective identifications, following politics of value similar to Babak's. Thus, Afshin's interest in promoting non-ethnic diversity as familiarity conflicted with the interests of a growing number of mem-

\footnotetext{
${ }^{14} \mathrm{~A}$ hammered dulcimer of Iranian origin.
} 
bers. The same barriers to capital creation do not necessarily bring agents to develop the same politics of value. In the end, Afshin dropped out. Much effort, resilience as well as Germany-specific capital is required to sustain politics of value that aim at promoting diversity as familiarity and thus redefine the system of value that dominates in most German contexts.

Donya's disengagement in March 2013 marked the second rupture. In our discussion, the physician explained her withdrawal by a personal conflict with Yara which was mainly related to value politics within what may be defined as the social field formed by local Iranians. While trust based on long-term mutual acquaintance and a shared honari identification was the working principle of the group's social organization, in Donya's view, Yara was an outsider. She argued that no one knew Yara long enough to vouch for her trustworthiness. Indeed, prior to 2009, Yara had not been engaged in local Iranian social fields. She once told me: "Before 2009, I was German" (field notes, June 2013). Donya became suspicious of Yara's political allegiances, because had the impression that Yara was involved "everywhere", as she disposed, by 2012, of a large social network among locals of Iranian origin including important stakeholders.

The conflict between Donya and Yara increased as they disagreed on the values which they wanted the association to promote. Donya wanted Golestan to promote education, knowledge of Iranian (pre-Islamic) traditions, literature, acquaintance with Western high culture, democracy, human rights, and equality. In doing so, she wanted mark Golestan's adherence to the honari system of value that she defined in distinction to local "Iranian mainstream culture". However, Yara began to take over more and more responsibilities within the association. For example, Donya told me that Yara took over the organization of a party around the theme of Iranian music from the 1970s, which was initially Donya's project. After the event, Donya learnt that the DJ, an acquaintance of Yara, put on contemporary Iranian pop music, displayed the flag of the Pahlavi regime, and played the pre-revolutionary national anthem (Ey Irân). The former national anthem-a frequent element in Iranian public events in various locations of immigration (Gholami 2015, 90) — as well as the flag serve for people to distance themselves from the contemporary Iranian government and position themselves as royalists. Yet, the Iran-specific 
resources Yara put forward failed to mediate most of the values that were crucial to Donya.

These differences in taste relate to the women's diverging social origins: Yara told me that her sister is a hairdresser and I saw that her mother lives in a flat in a simple suburban three-story apartment building. Yet, she rents an apartment in the central upper middle-class neighborhood Rotherbaum, and explained me that a good economic situation was very important in her choice of a partner. Thus, through her engagement in Golestan, Yara aspired to upward social mobility from a social origin that endowed her with less inherited cultural resources than the founding members. Outraged, Donya had the impression that Yara had not only taken her place in the association, but changed Golestan's identity to one that fit her own strategies of capital creation. Not only newer, but also some of the founder members of Golestan acknowledged Yara's resources and supported her politics of value, and Donya left the association.

In sum, as people with different personal trajectories face similar barriers to creation capital in the country of residence, new alliances develop around shared strategies of capital creation. These observations confirm that "migrants actively create dynamics of validating cultural resources as capital, resulting in new forms of intra-migrant distinction" (Erel 2010, 656). For example, although Babak originally had a greater trust and affinity with Donya and Afshin, in dealing with barriers to the generation of capital in German social fields, he chose strategies of capital creation that sustained politics of value that were more similar to Yara's and those of the other new members.

Sharing the same politics of value is not a necessary condition to agreeing on collective strategies of capital creation, but certainly strengthens the group's potential for action, as we saw in the case of merchants. The conflicts considerably changed the group configuration, as Afshin and Donya's siblings followed their move and quit. Thus, as a result of the disputes, the group shifted from a space for the celebration of diversity as familiarity and the local recreation of - not exclusively Iranian-honari identities to a platform in which professionals of heterogeneous backgrounds collectively mobilize, through honari artifacts and identities, a 
neo-traditionalism which helps them to enhance their mediation of exoticism and, through assimilation, familiarity with German contexts.

\section{Collective Identifications Through Inclusion and Exclusion}

Having outlined how diverging strategies of capital creation and changing configurations within the association led to the withdrawal-the (self-)exclusion - of five founding members, what do subsequent processes of inclusion and exclusion tell us about the remaining members' collective identifications? How did they engage with systems of value that shape the social field of the German public sphere and the local Iranian social field?

Golestan's very first Stammtisch took place in an Iranian-run café in the Schanzenviertel in May 2013. I was sitting around a table with Babak, Ayda, and Said, while little by little Golestanis and prospective members arrived and introduced themselves. Everybody was of Iranian origin, most had immigrated as adults, and the common language was Persian. Then, a white-haired bearded man in his early seventies arrived.

Babak asked Ayda in Persian "Is that the guy you told me about?"

The man came towards our table and asked [in German] "You look like Persians, are you from association Golestan?"

We said "Of course", and he sat down at the far end of the table [...]. I was surprised that everybody continued to speak in Persian. The man later told me that he was a retired engineer and that he only very limited knowledge of Persian.

After a while, Babak said to Ayda "Ask the German what he wants with this calendar."

Sonja "Why don't you ask him yourself?"

Babak "I have no idea what this was about, it's you who have been in contact." They continued to talk about the man in Persian.

Finally, Babak addressed him in German and the man explained that he was looking for a Persian-speaker to help him with creating a culturally universal calendar. The man came over to us and asked Babak for help, 
but the artist evaded with an excuse and gave him the contact of an elderly acquaintance, instead. Before he left-much earlier than the rest of us - he tried to engage a group discussion in German.

He said that he took a picture of Golzar's mother, because she sat next to him at Golestan's Nowruz celebration. Half joking, half serious, Golzar commented in Persian "What do you want from my mother?" (Field notes, May 2013)

Golestanis thus made fun of and excluded the German man from group discussions. Of course, his advanced age compared to the other participants, as well as the fact that he talked lengthily about things that were not of great interest to others also contributed to his exclusion. These particularities aside, I noticed on several occasions that Golestanis made fun of people they categorized as Germans and intentionally excluded them through language barriers.

Strikingly, Golestan's public events were always bilingual or in German only, and took place in venues which testify of a high level of Western- or Germany-specific cultural resources (e.g. a Steiner school, a Museum), or in collaboration with prestigious local German cultural organizers. Thus, while access to group membership was restricted to people who spoke Persian or, at least, disposed of resources that conveyed an Iranian identification, events had the declared aim to target besides Iranians also a highly educated and well-situated German public.

Thus, Golestan's public events were geared toward the system of value of the German public sphere: they tried to get acknowledgment for their Iran-specific resources as capital for conveying exoticism, and yet fulfill the expectation of assimilation and familiarity with German cultural elements. For this purpose, they needed a German public. Yet, within the association, Golestanis created a different system of value, where resources that mediated familiarity with Iranian cultural elements, such as language, cultural references, and humor, were key. Consequently, people who, like the elderly German man, lacked these resources, were unable to create capital. In a similar way, Çetin Çelik (2015) finds "reactive ethnicity", that is, forwarding resources related to the country of origin in order to exclude Germans, to be a common response to the experience of 
exclusion among working class male youth of Turkish descent in Germany. In our case, another reason for the exclusion of Germans is that their incorporation would impede on the Golestanis' collective staging of Iranianness in German social fields. Thus, while Golestanis created an internal system of value that, as it seems here, opposes the one that dominates the social field of the German public sphere, they contradicted this counterpublic in (at least apparently) complying to the hegemonic evaluations in their public events.

A month later, I got to know Navid, a stout 34-year-old, with a round face, big, black-framed glasses and brown hair at shoulder length, at an exhibition which featured some of his posters. He told me that his father was a factory manager from Iran and that he was raised partly in the southern Iranian city of Shiraz, partly in the USA, and came to Germany as a student three years before. One of his grandmothers, however, was a Native American. It struck me that he has a rather English than Persian accent in German. When speaking Persian, he frequently interweaves English words. When I told him about Golestan, its artist identity, and their monthly meetings in a bar in the Schanzenviertel, reflecting identifications with local alternative and artistic subculture, he was surprised: "I never thought Iranians would meet there" (field notes, July 2013). Adding "I might work for them as a graphic designer", he accepted my proposition to join the next Stammtisch.

When Navid and I arrived at the bar, seven people were sitting around a table: the official members Babak, Yara, Farzan, and Golzar, as well as their friends Karim, Kaspar, and Shahram. When I introduced Navid, someone asked for his family name. After hearing the answer, Babak inquired "Are you related to the famous writer?" Navid confirmed that he was. We took a seat, and the group decided to make a round of introductions. Yara explained that Kaspar, a Munich-grown 24-year-old law student and child of a binational German-Iranian couple, does not speak Persian. She translated for him during the meeting. When it was Navid's turn,

he began to explain [in Persian] that he had recently finished his master, and that he wants to start a $\mathrm{PhD}$ in the following months. In Iran, he had studied at Tehran University (dâneshgâh tehrân). He said that he was half-American. 
Someone asked "Did you come here directly?"

Navid "No, I lived in the US and in London before."

Someone "Where about in the US?"

Navid "In New York, Ohio, and Louisiana. Because of my father's jobs."

Babak "What subject did you do your Master's in?"

Navid "Graphic design."

Yara "So you're an artist (honarmand)? Welcome! We already have some artists."

Navid "Why? Who else is an artist?"

Yara "We have Sadegh but he isn't here today, and Babak." (Field notes, July 2013)

The Golestanis' evaluation of Navid's resources gives more detailed insights into the internal system of value which their collective identifications relied on after the conflict. First, inquiring about his family namea practice I frequently witnessed in Iran as well as among people of Iranian origin living in Germany-allowed the members to identify him as a relative of a renowned writer and as a member of an urban upper middleclass family.

Second, as they ask him about his migratory trajectory, they indirectly evaluate the volume and distribution of his Western- and Germanyspecific resources. The apprehension of this evaluation is probably the reason why Navid spoke Persian even though he knew that Kaspar did not understand the language- - he avoided exposing his accent in German. Indeed, I repeatedly noticed that Golestanis sought distinction from Iranians who they found lacking Germany-specific resources. For example, Babak and Yara frequently imitated the Persian accent in German language, ${ }^{15}$ which gave rise to much laughter among their public.

Third, a criterion on which Navid was evaluated but which does not appear in the vignette was his age. A friend and social scientist explained me that his father was a Golestani by exception: the board had told him that it does not want people of his age in the association. Research in other national contexts shows that the objectives of Iranian associations change with the age of its members (Van den Bos and Achbari 2007;

\footnotetext{
${ }^{15}$ For native Persian speakers, combinations of different consecutive consonants in German are difficult to pronounce if they are not preceded by a vowel. This is why they often add a vowel, saying, for example, Estrasse instead of Strasse (street).
} 
Ghorashi and Boersma 2009; Maghbouleh 2013). This observation needs to be understood in the context of constructed generational divides relative to political, social, and economic conditions in Iran: those who experienced the Islamic revolution in Iran as young adults are called the "first generation". Correspondingly, the category "second generation", with which Babak identifies, refers to people who were children at the time of the revolution, and whose youth was shaped by the new political order and the Iran-Iraq war. Finally, people who claim to belong to the "third generation", or the "burnt generation" (nasl-e sukhte), stress that they never knew any other political order than that of the Islamic Republic (Khosravi 2008, 4f.). Golestan's aim, as declared by Yara in the talk show and on videos published on the association's website, is to address the younger generations, regardless of whether they grew up in Germany or in Iran, supposedly in order to bridge political differences that caused divisions among their parents.

Finally, only when Navid revealed that he was an artist did Yara explicitly welcome him to the group. When we left, Yara asked Navid for his email address and when I met him two weeks later, he told me that she had proposed him to take over a mandate for a friend. In the valorization of an artist background, the interests of different members conflate. First, some of the founding members, like Babak, still aim at establishing professional networks which sustains the founding members' tentative to build Golestan's identity on the honari imaginary. Plus, adherence to the honari imaginary is a way for people with modest inherited resources, like Yara, to claim belonging to the intelligentsia and enact upward social mobility. Second, the system of value of the honari imaginary has the advantage of sharing some of the key values prevalent in German social fields, that is, democracy, equality, and human rights, but also Western high culture. For example, the female Golestanis made up less and dressed more casually than most local women of Iranian origin. In doing so, they showed adherence to the value of gender equality that is important both in honari contexts and in German society, where women tend to value rather practical dress styles. People in Hamburg, in particular, are known for the Hamburger Understatement, that is, privileging modesty to ostentation - a value presumably dating back to the time of the Hanse (Knödler 
2014). This trend is even stronger among people who consider themselves to be a part of the artist and alternative subcultures. Third, and relatedly, the internal system of value shifted from the importance of transnational political engagement toward staging exoticism in German contexts (Ghorashi 2004; Kelly 2011; Maghbouleh 2013; Gholami 2015). Significantly, out of six bands in FusIran's lineup, only one was actually based in Iran and it can perform legally.

Thus, Navid's resources mediated values that were key in the social field of the association, namely an Iranian identification, an upper middle-class background, education, youth, professionalism, adherence to the honari imaginary, and familiarity with Western cultural contexts. On this basis, Golestanis wanted to include Navid in the group. However, he did not want to become a member of Golestan and spent most of the Stammtisch talking with Karim and Kaspar, who are not officially members of Golestan, and who nourish strong German identifications.

These two instances of boundary-making show that, while Golestan's internal system of value is distinct from the one that shapes the German public sphere, the latter shapes the former to the extent that, here too, Germany-specific resources that mediate familiarity are key for capital creation. Moreover, as the honari imaginary is historically shaped by systems of value which highlight Western cultural elements, the systems of value within the transnational social field of Iranian artists and arty people as well as those prevalent in German society overlap. Thus, while Golestan's internal system of value opposes the one that dominates in the German public sphere in valuing certain Iran-specific resources, it concurs with it in highlighting the importance of Germany-specific resources. The pervasiveness of systems of value in which familiarity with the West is central across diverse local and transnational social fields tends to limit migrants' possibilities to agree on collective politics of value.

Yet, even if Golestanis' room for creative action is restricted for these reasons, their politics of value may be very subtle, as we will see in the way they are staging Iranianness in a second public media representation, almost two years after Afshin and Yara's participation in the talk show. 


\section{Staging "Iranianness in Hamburg"}

In April 2014, a film team producing short documentaries for a German public channel, making diverting portrays of migrant "communities" living in different German cities, contacted Golestan to propose the participation in a new production. The members agreed and Golzar invited the film team, as well as 12 Golestanis and friends, 9 men and 3 women, for dinner at her place. When I arrived, I found the Golestanis sitting on chairs and sofas along the walls of the living room-a spatial configuration that reminded me of receptions (mehmunis) I experienced in Iran in rather traditional contexts - with a blond and jocular German journalist in their midst. A cameraman, a sound technician, and a program manager, a women in her late twenties who was herself of Iranian origin, stood in the center of the room, filming. After everybody presented himself, the journalist asked questions like

What do you talk about when you're among yourselves?

or,

What do you say about Germany?

or,

Don't you think Germans are cold and unfriendly? As a Southerner, I personally find Northerners cold, too.

Although we had just presented ourselves and our heterogeneous trajectories, the journalist defined us as Iranians, and not as Germans. When talk came to the code of politeness (ta'ârof), we explained at length its particularities. In showing a critical distance from an element central to sociability in Iranian contexts, we displayed important Germany-specific resources and collectively claimed their recognition as a capital. Golzar had cooked an Iranian dinner. While the Golestanis and the journalist remained in the living room, holding their plates in their hands, the film team was eating apart from us in the kitchen. I sat next to Babak, when 
he suggested, in Persian, "Guys, let's all stand up and do a quick dance. On three!"

Golzar "They will take us for fools!"

Babak "That's the whole point!"

Golzar "Where do we get the music from?"

Babak "We do it ourselves."

Golzar "But I can't do that!"

The program manager, who understood Persian, alerted her colleagues "Film! They're going to dance!"

The Golestanis wanted to dance although the surprise was spoiled. Kian stood up and acted as if he got upset by Golzar "Pedareman-o dar âvordi [You go on my nervs]! You stop arguing now!”

We counted to three, then stood up, clapping hands and half-dancing. Golzar danced alone in our midst [Image 4.3].

After two minutes Kian said "And now we sit down and do as if nothing had happened." That was what we did. (Field notes, April 2014)

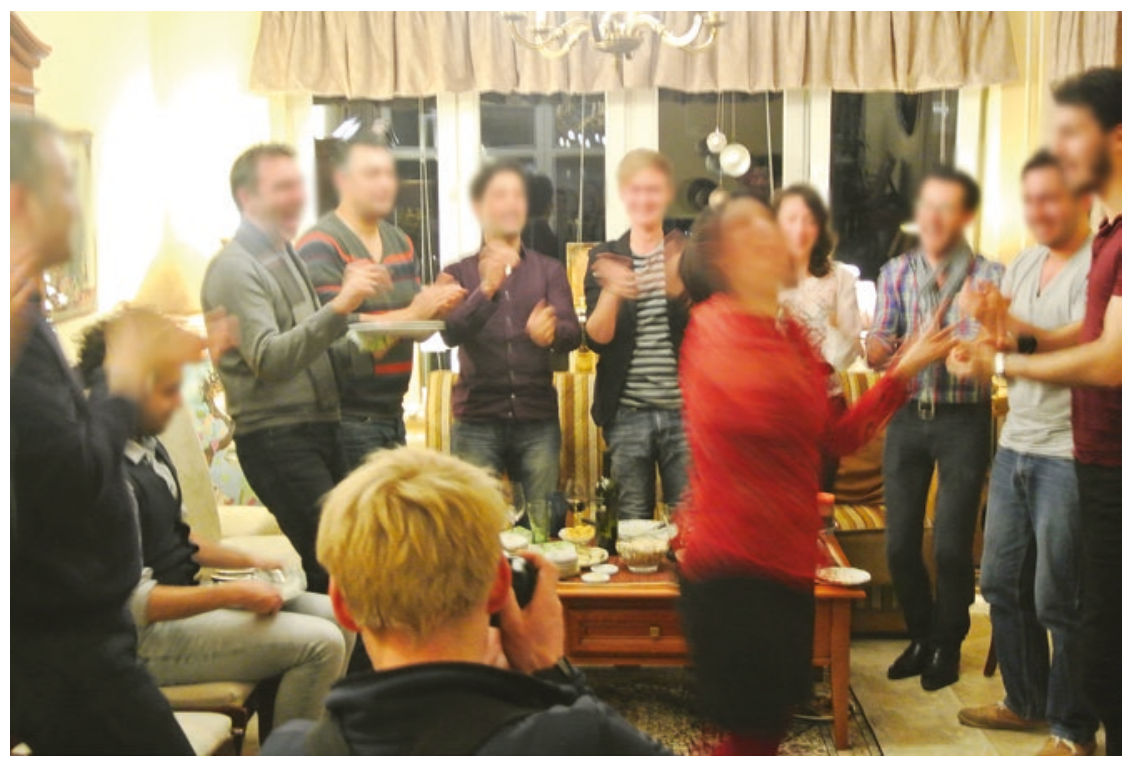

Image 4.3 Golzar dances in front of German journalists in her living room. (April 2014, picture taken by a member of the film crew with the author's camera, anonymized) 
What the film team had expected — despite the program manager being of Iranian origin - was the display of collective cultural difference. In the initial discussion, however, this difference was mediated, because we showed that we dispose of important Germany-specific resources. However, unconsciously or consciously, the Golestanis understood that in order to be interesting for the film team, there was a need to stage Iranian identifications-in a way, a need for self-exoticization. Strikingly, however, we staged the difference in a way that its performative character became obvious. Ultimately, in a very subtle way, we thus ridiculed the Germans' interest in the exotic, as a sort of incomplete and disavowed critique (Li 2019). The producer may have understood these discreet politics of value, because the final documentation did not contain any of the scenes shot during that evening.

In the face of the difficulty to their having Germany-specific resources valorized because of the Golestanis' categorization as culturally different, appropriating the category by staging secular and apolitical Iranian identifications became increasingly important to the association's activities. Cattacin and Domenig $(2014,724)$ stated:

Having and defending something like a culture thus becomes a way to tell others that they do not possess a monopoly on culture, which turns culture into a topic of sameness, and no longer of difference. The lack of recognition is, therefore, the reason why associations invent culture and invest in the marketing of a specific cultural image.

Golestanis thereby had a critical distance toward their self-exoticization and tried indirectly to act upon the system of value prevailing in the German public sphere. The context of associations is particularly favorable for claiming recognition of Iran-specific resources as capital. However, the fact of complying, even if in incomplete ways, with the dominant system of value tends to, if not perpetuate, at least prolong the barriers to capital creation that derive from migrants' perceived lack of familiarity in combination with their construction as racial Others.

\section{Epilogue}

In our Skype interview in November 2015, Donya told me that after much consideration, she went to the concert of one of her favorite bands 
from Iran, Pallett, organized by Golestan in Hamburg in the fall of 2015. "There were not even three likeable faces", she commented. When I asked her what she meant by that, she said "They were all highly made up." Moreover, she explained me that when she recently told Babak that she considered rejoining Golestan, he replied "There is nothing for you to find there anymore, people are all the same, there is no diversity" (field notes, November 2015). In spring 2014, Sadegh told me that he would prefer Golestanis to be older and more settled.

Sonja "But many are also artists."

Sadegh "Yes, but that's not necessarily good."

Sonja "Why not?" I thought that was what he wanted.

Sadegh "They expect something that does not correspond to reality. Many will leave again. Several already left. Some people only participate because they find it useful. At the moment I help Zian, and I will help Parham when the time has come. But I would have helped them even if they were not members of Golestan." (Field notes, April 2014)

Their statements confirm a development I traced in this chapter: dynamics taking place within Golestan take it ever further away from its initial left-wing artist and honari identifications in order to provide images that speak to a larger public_-both German and Iranian.

While the previous chapter was about the way migrants' collective identifications develop as a collective engagement with changing systems of values in different social fields, in this chapter, my aim was to show, how such a collectivity develops from an in-group perspective. How do processes of evaluation within an association relate to systems of value that prevail in the German public sphere, the local Iranian social field and the transnational social field of Iranians identifying as honari?

German approaches to immigration rely on a paradox: they require assimilation to and familiarity with what is defined as German, but the racialization of migrants simultaneously makes this objective barely attainable, as being German and having other cultural identifications tends to be seen as mutually exclusive. In this context, associations provide spaces in which migrants may find ways to contest or circumvent barriers to capital creation they meet in the society of residence.

Collective identifications may be part of politics of value that engage with hegemonic valuations through the formation of so-called counter- 
publics (Nicholls and Uitermark 2016). They emerge between people whose strategies of capital creation share the same objective in the same social field at a given time. I showed that through internal boundarymaking, Golestanis created an internal system of value. However, their system of value only partly opposes the one that prevails in the German public sphere. Both systems of value as well as the one that sustains the honari imaginary intersect in granting familiarity with Germany or the West a key position. The pervasiveness of the valorization of Westernspecific resources across local and transnational social fields and migrants' unequal individual resources pose important obstacles to their collective politics of value. I showed in Chap. 3 that migrants' politics of value do have the power to redefine the value of their resources, but an important key to their success is long-term engagement and collective action.

Confirming related ethnographies (Graham and Khosravi 1997; Sanadjian 2000; Ghorashi 2004), I showed that Golestanis tried to stage Iranian identifications alternative to the image of the Islamic Republic. After members who promoted non-ethnic diversity as a value connected to familiarity left the association, the collective strategies of capital creation which the remaining Golestanis agreed upon are part of politics of value that aim at enhancing Iran-specific resources' exoticism and mediating assimilation and familiarity through Germany-specific resources. This may temporarily help to overcome certain barriers to capital creation. However, it barely acts on the cause of the barrier, that is, prevailing systems of value. An active contestation of ethnic and national categorizations requires more Germany-specific resources, and may be more laborious and protracted, but ultimately more efficient in acting upon systems of value that produce and sustain structural racism.

In this chapter, I observed that people may implement incompatible or even competitive strategies of capital creation to engage with the systems of value that highlight familiarity with the West. In the next chapter, I interrogate its causes and effects through a micro-perspective, examining boundary-making between three colleagues and friends working in the film business. 


\section{References}

Abrahamian, Ervand. 2008. A History of Modern Iran. Cambridge: Cambridge University Press.

Alexanian, Janet A. 2011. Eyewitness Accounts and Political Claims: Transnational Responses to the 2009 Postelection Protests in Iran. Comparative Studies of South Asia, Africa and the Middle East 31 (2): 425-442. https://doi.org/10.1215/1089201X-1264334.

Amelina, Anna, and Thomas Faist. 2008. Turkish Migrant Associations in Germany: Between Integration Pressure and Transnational Linkages. Revue européenne des migrations internationales [online] 24 (2). http://remi. revues.org/4542

Bail, Christopher A. 2008. The Configuration of Symbolic Boundaries Against Immigrants in Europe. American Sociological Review 73 (1): 37-59.

Bourdieu, Pierre. 1979. La distinction. Critique sociale du jugement. Paris: Editions de Minuit.

Brubaker, Rogers, and Frederick Cooper. 2000. Beyond 'Identity'. Theory and Society 29 (1): 1-47. https://doi.org/10.1023/A:1007068714468.

Bührmann, Andrea D., and Karen Schönwälder. 2017. Public Organisations and Diversity: Approaches to an Under-Researched Topic. Journal of Ethnic and Migration Studies 43 (10): 1635-1643. https://doi.org/10.1080/13691 83X.2017.1293588.

Bundesministerium der Justiz und für Verbraucherschutz. 2015. Staatsangehörigkeitsgesetz (StAG). http://www.gesetze-im-internet.de/bundesrecht/ rustag/gesamt.pdf

Cattacin, Sandro, and Dagmar Domenig. 2014. Why Do Transnationally Mobile People Volunteer? Insights from a Swiss Case Study. VOLUNTAS: International Journal of Voluntary and Nonprofit Organizations 25: 707-729.

Cederberg, Maja. 2015. Embodied Cultural Capital and the Study of Ethnic Inequalities. In Migrant Capital: Networks, Identities and Strategies, Migration, Diasporas and Citizenship, ed. Louise Ryan, Umut Erel, and Alessio D’Angelo, 33-47. Hampshire/New York: Palgrave Macmillan.

Çelik, Çetin. 2015. 'Having a German Passport Will Not Make Me German': Reactive Ethnicity and Oppositional Identity among Disadvantaged Male Turkish Second-Generation Youth in Germany. Ethnic and Racial Studies 38 (9): 1646-1662.

. 2017. Disadvantaged, But Morally Superior: Ethnic Boundary Making Strategies of Second-Generation Male Turkish Immigrant Youth in Germany. Identities 25: 1-19. https://doi.org/10.1080/1070289X.2017.1305218. 
Ehrkamp, Patricia. 2006. 'We Turks Are No Germans': Assimilation Discourses and the Dialectical Construction of Identities in Germany. Environment and Planning A 38 (9): 1673-1692. https://doi.org/10.1068/a38148.

El-Tayeb, Fatima. 2004. Kanak Attak! Hiphop und (Anti-)Identitätsmodelle der 'Zweiten Generation'. In Jenseits des Paradigmas kultureller Differenz: Neue Perspektiven auf Einwanderer aus der Türkei, ed. Martin Sökefeld, 95-110. Bielefeld: transcript Verlag.

- 2016. Undeutsch: Die Konstruktion des Anderen in der postmigrantischen Gesellschaft. Bielefeld: transcript Verlag.

Emami, K. 1986. Art in Iran Xi. Post-Qajar. Encyclopaedia Iranica II (6): 640-646. Erel, Umut. 2010. Migrating Cultural Capital: Bourdieu in Migration Studies. Sociology 44 (4): 642-660. https://doi.org/10.1177/0038038510369363.

Fleming, Crystal, Michèle Lamont, and Jessica Welburn. 2012. African Americans Respond to Stigmatization: The Meanings and Salience of Confronting, Deflecting Conflict, Educating the Ignorant and 'Managing the Self'. Ethnic and Racial Studies 35 (3): 400-417.

Gaserow, Vera. 1995. Denkwürdige Anregung. Die Zeit, May 19. http://www. zeit.de/1995/19/Denkwuerdige_Anregung/komplettansicht

Gholami, Reza. 2015. Secularism and Identity: Non-Islamiosity in the Iranian Diaspora, Studies in Migration and Diaspora. Surrey/Burlington: Ashgate Publishing Limited.

Ghorashi, Halleh. 2004. How Dual Is Transnational Identity? A Debate on Dual Positioning of Diaspora Organizations. Culture and Organization 10 (4): 329-340. https://doi.org/10.1080/1475955042000313768.

Ghorashi, Halleh, and Kees Boersma. 2009. The 'Iranian Diaspora' and the New Media: From Political Action to Humanitarian Help. Development and Change 40 (4): 667-691. https://doi.org/10.1111/j.1467-7660.2009.01567.x. Goldberg, David Theo. 2006. Racial Europeanization. Ethnic and Racial Studies 29 (2): 331-364. https://doi.org/10.1080/01419870500465611.

Graham, Mark, and Shahram Khosravi. 1997. Home Is Where You Make It:

Repatriation and Diaspora Culture among Iranians in Sweden. Journal of Refugee Studies 10 (2): 115-133.

Grigor, Talinn. 2012. Return of the Avant-Garde to the Streets of Tehran. In Iranian Nationalism Revisited, ed. Kamran Aghai and Afshin Marashi, 235-254. Austin: University of Texas Press.

Gruner, Sabine. 2010. 'The Others Don't Want ...'. Small-Scale Segregation: Hegemonic Public Discourses and Racial Boundaries in German Neighbourhoods. Journal of Ethnic and Migration Studies 36 (2): 275-292. https://doi.org/10.1080/13691830903387402. 
Hall, Suzanne M. 2017. Mooring 'Super-Diversity' to a Brutal Migration Milieu. Ethnic and Racial Studies 40 (9): 1562-1573. https://doi.org/10.108 0/01419870.2017.1300296.

Halter, Marilyn. 2007. Shopping for Identity: The Marketing of Ethnicity. New York: Schocken Books.

Kelly, Melissa. 2011. Transnational Diasporic Identities: Unity and Diversity in Iranian-Focused Organizations in Sweden. Comparative Studies of South Asia, Africa and the Middle East 31 (2): 443-454.

Kelly, Philip, and Tom Lusis. 2006. Migration and the Transnational Habitus: Evidence from Canada and the Philippines. Environment and Planning A 38 (5): 831-847.

Keshmirshekan, Hamid. 2010. The Question of Identity Vis-à-Vis Exoticism in Contemporary Iranian Art. Iranian Studies 43 (4): 489-512. https://doi.org/ 10.1080/00210862.2010.495566.

Khosravi, Shahram. 2008. Young and Defiant in Tehran. Philadelphia: University of Pennsylvania Press.

Knödler, Gernot. 2014. Reeder Schües über das Hanseatische: 'Das wäre angeberisch.' TAZ, July 2. http://www.taz.de/!5049021/

Li, Tania Murray. 2019. Politics, Interrupted. Anthropological Theory 19 (1): 29-53. https://doi.org/10.1177/1463499618785330.

Maghbouleh, Neda. 2013. The Ta'arof Tournament: Cultural Performances of Ethno-National Identity at a Diasporic Summer Camp. Ethnic and Racial Studies 36 (5): 818-837. https://doi.org/10.1080/01419870.2011.648649.

Malek, Amy. 2011. Public Performances of Identity Negotiation in the Iranian Diaspora: The New York Persian Day Parade. Comparative Studies of South Asia, Africa and the Middle East 31 (2): 388-410. https://doi.org/10.1215/1 $089201 X-1264316$.

Mandel, Ruth. 2008. Cosmopolitan Anxieties: Turkish Challenges to Citizenship and Belonging in Germany. Durham/London: Duke University Press.

Moya, Jose C. 2005. Immigrants and Associations: A Global and Historical Perspective. Journal of Ethnic and Migration Studies 31 (5): 833-864. https:// doi.org/10.1080/13691830500178147.

Naegler, Laura. 2012. Gentrification and Resistance: Cultural Criminology, Control, and the Commodification of Urban Protest in Hamburg, Hamburger Studien Zur Kriminologie Und Kriminalpolitik. Münster: Lit Verlag.

Nicholls, Walter J., and Justus Uitermark. 2016. Migrant Cities: Place, Power, and Voice in the Era of Super Diversity. Journal of Ethnic and Migration Studies 42 (6): 877-892. https://doi.org/10.1080/1369183X.2015.1126088. 
Ong, Aihwa. 1999. Flexible Citizenship: The Cultural Logics of Transnationality. Durham: Duke University Press.

Prashizky, Anna, and Larissa Remennick. 2015. Cultural Capital in Migration: Fishka Association of Young Russian-Speaking Adults in Tel-Aviv, Israel. Journal of Intercultural Studies 36 (1): 17-34. https://doi.org/10.1080/07256 868.2014.990364.

Sadjed, Ariane. 2012. "Shopping for Freedom" in Der Islamischen Republik: Widerstand Und Konformismus Im Konsumverhalten Der Iranischen Mittelschicht, Kultur Und Soziale Praxis. Bielefeld: transcript Verlag.

Sanadjian, Manuchehr. 2000. 'They Got Game' Asylum Rights and Marginality in the Diaspora: The World-Cup and Iranian Exiles. Social Identities 6 (2): 143-164. https://doi.org/10.1080/13504630050032044.

Schiller, Maria. 2016. European Cities, Municipal Organizations and Diversity: The New Politics of Difference, Global Diversities. Basingstoke: Palgrave Macmillan.

Shooman, Yasemin. 2014. “... Weil ihre Kultur so ist”: Narrative des antimuslimischen Rassismus, Kultur und soziale Praxis. Bielefeld: transcript Verlag.

Sökefeld, Martin. 2004. Das Paradigma kultureller Differenz: Zur Forschung und Diskussion über Migranten aus der Türkei in Deutschland. In Jenseits des Paradigmas kultureller Differenz: Neue Perspektiven auf Einwanderer aus der Türkei, ed. Martin Sökefeld, 9-33. Bielefeld: transcript Verlag.

Spellman, Kathryn. 2004. Religion and Nation: Iranian Local and Transnational Networks in Britain. Oxford: Berghahn Books.

Strasser, Sabine. 2006. “Die dritte Türkenbelagerung?” Bewegte Zugehörigkeiten, strategische Repräsentationen und die Bekämpfung von Ungleichheiten. Kurswechsel. Zeitschrift für Gesellschafts-, Wirtschafts- Und Umweltpolitische Alternativen 2: 88-98.

2008. Europe's Other. European Societies 10 (2): 177-195. https://doi. org/10.1080/14616690701835261.

Van den Bos, Matthijs, and Wahideh Achbari. 2007. Cultural Migration: Networks of Iranian Organizations in the Netherlands. Migration Letters 4 (2): 171-181.

Weiss, Anja. 2001. Rassismus als symbolisch vermittelte Dimension sozialer Ungerechtigkeit. In Klasse und Klassifikation. Die symbolische Dimension sozialer Ungerechtigkeit, ed. Anja Weiss, Cornelia Koppetsch, Albert Scharenberg, and Oliver Schmidtke, 79-108. Opladen: Westdeutscher Verlag. 
Open Access This chapter is licensed under the terms of the Creative Commons Attribution 4.0 International License (http://creativecommons.org/licenses/ by/4.0/), which permits use, sharing, adaptation, distribution and reproduction in any medium or format, as long as you give appropriate credit to the original author(s) and the source, provide a link to the Creative Commons licence and indicate if changes were made.

The images or other third party material in this chapter are included in the chapter's Creative Commons licence, unless indicated otherwise in a credit line to the material. If material is not included in the chapter's Creative Commons licence and your intended use is not permitted by statutory regulation or exceeds the permitted use, you will need to obtain permission directly from the copyright holder.

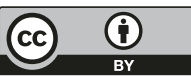

